\title{
Corporate Governance and Elites 1
}

\begin{abstract}
Using a qualitative methodology (interviews), we examine the relationship between the effectiveness of corporate governance mechanisms and elitist interventions. In doing this, we identify three elitist groups - political, cultural and religious, and investigate how they shape the legitimacy and effectiveness (or otherwise) of the institutional drivers of corporate governance in Nigeria. We caution the widely-held notion in the literature which suggests that institutions act as a check on the behaviour of elites and influence how elites compete and emerge. Alternatively, we argue that elites, in the presence of institutional voids, can invent, circumvent and corrupt institutions.
\end{abstract}

Keywords: Corporate governance, elites, institutions, institutional theory, institutional voids, corruption.

\footnotetext{
${ }^{1}$ This article majorly constitutes a part in Nakpodia, F. (2016). An Assessment of Institutional Influences on Corporate Governance in Nigeria: A Multi-Stakeholder Perspective. Unpublished Doctoral thesis, Newcastle Business school, Northumbria University, UK
} 


\subsection{Introduction}

In the last two decades, the institutional theory has contributed to a richer understanding of the behaviour and reactions of stakeholders to issues of corporate governance (Aguilera \& Jackson, 2003; Judge, Douglas \& Kutan, 2008). It has stimulated research towards understanding the macro and micro institutional influences on corporate governance in varieties of capitalism (Adegbite \& Nakajima, 2011; Filatotchev, Jackson \& Nakajima, 2013, Lien \& Li, 2013). However, given the promising prospects of the institutionalism-based corporate governance discourse, its usefulness in explaining corporate governance, especially in weak institutional contexts, has suffered from an important limitation. This relates to the role of elites (see Domhoff, 1990; Vergara, 2013) in shaping corporate governance through their influences on institutional (e.g. regulatory) mechanisms.

'Elite' was used in the $17^{\text {th }}$ century to describe items of particular excellence, but the usage has been extended to refer to superior social groups (Bottomore, 2006). Elites represent a small group of influential people that control a disproportionate amount of wealth, privilege or power in society (Mills, 2000). Elites, in each sphere of activity, have succeeded or arrived at a higher echelon in the hierarchy (Aron, 1999). They include business (corporate) elites (Sikka, 2017), community elites, religious elites (Barro \& McCleary, 2003), political elites (Aplin \& Hegarty, 1980; Hadani, 2012) and professional elites (Aron, 1999). Essentially, elites have no restriction regarding their locale. They dictate the governance process in institutional settings, be it religious, military, academic, professions, community, or industry (Rizvi, 2015). In doing this, they use power and domination to influence the governance networks that promote institutional and organisational goals (Maclean, Harvey \& Chia, 2010).

The relationship between elites and institutions is important, given that elites influence institutions and vice versa (Acemoglu \& Robinson, 2008). Higley and Lengyel (2000) note that institutions limit elite unity or disunity, differentiation or circulation, but these elite groups, in turn, influence the operation of institutions and may be able to overwhelm existing institutional structures. On the one hand, Higley and Lengyel (2000) note that in stable democracies, institutions constrain elites strongly; however, in economies undergoing fundamental changes where institutions are typically in flux (deinstitutionalisation), elites possess wider latitudes of choice and action. On the other hand, multinational corporations are expected to accommodate operational dynamics that allow them to respond appropriately to local institutional demands. As a result, multinational firms who are subject to institutional control in their home country 
may find the void of such control filled by elites in their host (developing) countries. Ahrens and Ferry $(2015 ; 2016)$ show how elites (e.g. government agencies), using state machinery, can influence the perception of citizens and stakeholders. However, despite the vital role of elites, especially in weak institutional contexts, there is a limited research on them. This is because elites are, by their nature, difficult to penetrate (Hertz \& Imber, 1995). They characteristically invent barriers that set their members apart from the rest of the society, resulting in "class belongingness' (see Catchpowle \& Smyth, 2016). Therefore, in this paper, we examine the relationship between elitist influences and the effectiveness of institutional mechanisms for corporate governance in developing economies.

The literature on corporate governance in developing countries has adopted an institutional perspective (Peng, Wang \& Jiang, 2008), but what remains unknown is a clear identification of the shapers of corporate governance institutional effectiveness. The extant literature in this space (Lau et al. 2007; Zattoni \& Cuomo, 2008; Ntim \& Soobaroyen, 2013) has documented weaknesses in the business environments at both macro and micro levels. This literature has however paid limited attention to the relationship between institutions and elites (Zald \& Lounsbury, 2010; Khan, 2012). We contribute to the literature on the institutional theory of corporate governance, by examining the role of elites, as institutional influencers, especially in developing economies. We rely on the notion of "institutional void" to deepen our understanding of elitist influences. Institutional voids can provide opportunities for substitution by other institutional arrangements established by elites to influence institutional outcomes (see Lepoutre \& Valente, 2012; Sikka, 2017). As such, we investigate the extent to which institutional voids and elites have provided the conditions for the growing levels of corruption and poor corporate governance in weak institutional contexts. In doing this, we identify the instruments employed by elites in influencing corporate governance outcomes. Our research, therefore, seeks to address the question:

To what extent is the corporate governance system in Nigeria a reflection of elitist influences?

Nigeria, as a research context, presents an appropriate case study to understand how the main institutional factors of corporate governance respond to the influences of elites (Yakassai, 2001; Ahunwan, 2002; Okike, 2007). Apart from being a leading economy in Africa, it is at the forefront of corporate governance research in the continent, particularly regarding the institutional antecedents of good corporate governance (Adegbite, 2015). As most Anglophone 
countries in Africa share similarities in their institutional environments (Tsamenyi \& Uddin, 2009), our findings provide relevant cross-country insights into the role of elites in corporate governance. We show how the institutional elements which permit a robust corporate governance system are frustrated by institutional voids that mirror elitist preferences. For example, we examine the herding power of religion to understand how under-researched religious elites influence corporate governance outcomes.

The rest of this paper proceeds with a literature review and the theoretical frame of the research study. Here, we focus on institutional theory and its elements mainly institutional environment, institutions and institutional voids to examine the role of elites in corporate governance. Following on, we present our research design and methodology as well as the analysis and discussion of our findings. We conclude with some contributions, implications for practice and areas for future research.

\subsection{Corporate Governance, Institutional Theory, Elites and Corruption}

Corporate governance denotes a system for directing and controlling companies (Cadbury, 1992), assures finance suppliers to firms of getting a return on their investment (Shleifer and Vishny, 1997), and establishes a system of checks and balances (Solomon, 2013). The concept of corporate governance is deeply situated within the sphere of agency theory (Jensen \& Meckling, 1976; Shleifer \& Vishny, 1997). Lubatkin, Lane, Collin and Very (2007) however note that the agency theory relies on assumptions that reduce the complexity of the corporate governance phenomenon. Aguilera and Jackson (2003), for instance, argue that the agency theory fails to sufficiently explore how institutional embeddedness influence corporate governance. Alternatively, institutional theory examines the deeper and more resilient aspects of social structure, investigating the processes by which certain structures become established as guidelines for social behaviour (Scott, 2004). Institutional theory helps us to understand why and how organisations relate to their institutional environments (Suddaby, 2010). Institutional environments have become the anchor for understanding the institutional theory, with institutional theorists contending that the institutional environment, rather than market pressures, inspires the formal structures in an organisation (Meyer \& Rowan, 1977).

In addition to the institutional environment, scholars have also studied institutional theory by exploring institutions. Institutions, as enduring features of social life (Giddens, 1984), are any collectively accepted system of rules by which societies establish institutional beliefs (Searle, 
2005). They not only represent a system of established and accepted social rules that structure social interactions (Hodgson, 2006), but comprise elements that provide stability and meaning to social life (Scott, 2014). Thus, institutions not only possess the capacity to constrain or enable behaviour (North, 1990) but also exhibits a permanency characteristic, as a tool for building robust institutions (Dulbecco \& Renard, 2003). On this understanding, institutional theory acknowledges that institutions are enduring entities (Maguire \& Hardy, 2009), maintained over prolonged periods (Dacin \& Dacin, 2008), and highly resistant to change (Zucker, 1987).

Institutions can also mirror social problems, such as corruption (Omololu, 2007). Institutions may be corrupt giving rise to political or country risk (see Everett, Neu \& Rahaman, 2007). This risk is prevalent in developing economies with considerable natural resources but weak regulation, thereby offering immense possibilities for corruption (Ferry, Zakaria, Zakaria \& Slack, 2017). Hoskisson, Eden, Lau and Wright (2000) note that it is easier to engage in corruption in environments that lack functional governance structures, independent checks and balances, transparent reporting standards, and efficient judicial systems. Osuagwu and Obumneke (2013) link the persistence of these problems to the activities of profit-seeking and corrupt political elites. In acknowledging the interaction between institutions and elites, the literature has demonstrated how one produces the other. For example, Jackson (2010) notes that as broader institutional environments influence the preferences of actors, institutions equally reflect the biases (e.g. corrupt leanings) of actors, thereby affirming the influence of elites on institutional outcomes. Mair and Marti, (2009) suggest that opportunity spaces in the institutional environment reinforce the influence of elites on institutions rather than the widelyreported institutional weakness. These opportunity spaces represent institutional voids.

Institutional voids represent situations where institutional arrangements that support markets are absent, weak, or incapable of achieving the expectations that prompted their establishment (Mair \& Marti, 2009; Amaeshi, Adegbite \& Rajwani, 2016). Unpredictable government regulations, the absence of specialist intermediaries, underdeveloped capital market, and weak contract-enforcing mechanisms characterise institutional voids (Aguilera \& Jackson, 2010; Li \& Qian, 2013). These voids obstruct the efficient functioning of markets thereby increasing the cost of transactions (Khanna \& Palepu, 2000). The literature examining institutional voids have emphasised two areas. The first relates to the institutional environment that promotes institutional voids (Luiz \& Stewart, 2014; Fainshmidt et al., 2016), whereas the second focuses 
on the outcomes created by institutional voids (Wu, 2005; Ngobo \& Fouda, 2012). The challenge posed by institutional voids in developing economies is receiving scholarly attention. For instance, Fainshmidt et al. (2016) note that African countries experience deep, persistent and substantial institutional voids (see also Amaeshi et al., 2016). The presence of institutional voids explain increasing corruption (Wu, 2005; Luiz and Stewart, 2014), and the lack of political accountability and stability (Ngobo \& Fouda, 2012), among others.

The opportunity spaces created by institutional voids further facilitate the emergence and strengthening of elites in response to institutional voids. Elites gain dominance in the environment of government corruption and weak enforcement of business laws (Khanna \& Palepu, 2000; Filatotchev et al. 2013). Elites can reinforce their influence as they engage their extensive networks to affect market involvement. This is consistent with a form of institutional void which impedes market participation, as identified in Mair and Marti (2009). For example, Neu et al. (2010) examined an IMF structural adjustment program and the role of accounting technologies and agents within that programme in the Nigerian banking sector. In reporting the presence of elitist power, they note that despite the potential disciplinary power of an accounting system, that 'power' is ineffectual when the objectives of an accounting system are inconsistent with the desire of elites (see also, Catchpowle \& Smyth, 2016). This permits the expression of the outputs of institutional voids notably corruption.

Corruption is an act in which the power of public office is used for personal gain in a way that breaches the rules of the game such as in the illegal application of public resources and abuse of standard processes (Jain, 2001). The description in Jain (2001) suggests that corruption mostly finds expression in the public sector. This position is noted in Shleifer and Vishny (1993) and Ferry et al. (2016), rationalising that the structure of government institutions and that of the political process define the level of corruption. They posit that governments that fail to control their agencies experience high corruption levels. The preceding views are consistent with the notion of demand-side corruption. Wu (2005) argued that demand-side corruption (taker) resonates with government officials. The context of corruption is however complemented by its supply-side. Wu (2005) explained that supply-side (giver) corruption originates from the business (private) sector, as rent-seeking entrepreneurs seek to exploit political and other influences to their benefit. 
The literature (Jain, 2001; Caron, Ficici, \& Richter, 2012) reports a negative relationship between governance and corruption, indicating that corporate governance practices are frustrated in countries with high levels of corruption. Given the negative effects of corruption, attempts have been made to examine its motivations. Aidt (2003), relying on Jain's (2001) view of corruption, articulates three conditions that trigger corruption. These include the possession of discretionary power, the extraction of economic rents and the existence of weak institutions. Ogbeidi (2012) (discretionary power), Tignor (1993) and Osoba (1996) (economic rents) and Adegbite and Nakajima (2011) (weak institutions) show that these conditions drive corruption in developing economies such as Nigeria. These elements not only combine to support each other but also provide the mechanism for institutional exploitations by elites.

Neu, Everett and Rahaman (2013) also demonstrate how macro-level elite influences trickle downward and frame audit judgements, in a way which restricts auditors' ability to detect and report on potentially corrupt activities. They demonstrate how elite-led corrupt networks skilfully employ accounting practices and social interactions to enable corruption. In particular, the emergence of corporate elites has resulted in 'managerialism' where top managers possess extensive powers to pursue their interests with the minimal constraint from shareholders (Davis, 2005; Lozano, Martinez \& Pindado, 2016; Sikka, 2017). This outcome bears sizable consequences for corporate governance as corporate elites face several attempts to promote corporate governance (Sariol \& Abebe, 2017), stemming from the increasing power of stakeholders and greater board independence, amongst others.

In understanding elitist influences, it is of particular importance to appreciate the cross-cultural distinctiveness of an institutional environment when considering how elites gain ascendancy to positions of power. This may imply a variance in the role of elites in different business contexts. The practice of corporate governance represents one of many structures that have been affected by the variations in the role of elites in different countries. This problem is more pronounced amongst developing economies such as Nigeria, where the challenges in the institutional environment have provided opportunities for increased elitist influence (Rizvi, 2015). However, while the institutional theorising of corporate governance in Nigeria has gained momentum, limited attention has been paid to elitist influences. For example, Adegbite, Amaeshi and Nakajima (2013) examined the influences of three agents - international organisations, rating agencies and local institutions - on corporate governance in Nigeria. 
Oghojafor, George and Owoyemi (2012) focused on national culture and its implications for corporate governance. These studies adopt the conventional view of institutional theory which posits that institutions possess the capacity to check the behaviour of influencers such as elites. We contribute to the literature in this space by providing insights on the role of elites in shaping the institutional environment for corporate governance, in weak institutional settings. This is very important given the increasing doubts about the capacity of institutions to constrain unethical behaviours (Uche, Adegbite \& Jones, 2016; Egbe, Adegbite \& Yekini, 2017). We present our methodology next.

\subsection{Research Design and Methodology}

This paper adopts a qualitative, interpretivist research approach. According to Patton (2002, p.89), 'there is a very practical side to qualitative (research) methods that simply involves asking open-ended questions of people ...in real-world settings in order to solve problems.' Therefore, semi-structured interviews were carried out, whereby a series of questions were asked (Kvale \& Brinkmann, 2009), allowing the interviewer to vary the sequence of the questions as deemed necessary (Bryman, 2015). This approach, which favours a two-way communication, offered more opportunities to ask probing questions in reaction to a significant response. As a result, information generated from our semi-structured interviews did not only provide answers but also offered explanations for those answers (Flick, 2014). This therefore aided the collection of in-depth and nuanced qualitative data (Denscombe, 2010, EasterbySmith, Thorpe \& Jackson, 2012). This approach is consistent with previous studies on corporate governance in Nigeria (see, e.g. Osemeke \& Adegbite, 2016; Nakpodia, Adegbite, Amaeshi \& Owolabi, 2016). The interviews were conducted by one of the authors over a twomonth period, with each interview lasting on average 40 minutes (see Appendix 1 for interview guide)."

Given the qualitative nature of this research, we engaged corporate governance stakeholders in Nigeria as participants in this study. Sampling was undertaken using the judgement technique (see Marshall, 1996), based on pre-determined characteristics (Corbetta, 2003) that include position held in the organisation, work experience, industry spread and an understanding of elites. Based on this strategy, we contacted participants with appropriate profile through emails and telephone calls. Considering Hofstede, Hofstede and Minkov's (2010) cultural evaluation 
of Nigeria as a collectivist society ${ }^{2}$, we used personal contacts and snowballing technique to access participants. ${ }^{3}$ To ensure that all participants satisfy our predetermined characteristics, we matched participants identified via snowballing to the pre-agreed interviewee features. We employed these strategies (personal contacts and snowballing) simultaneously to identify other suitable participants. As cultural issues impact the number of interviews conducted in qualitative studies (Marshall et al., 2013), these techniques proved beneficial in securing access to interviewees (Denscombe, 2010, Stigliani \& Ravasi, 2012).

We conducted semi-structured interviews with elites who influence corporate governance outcomes in the country. Our understanding of elites relies on the descriptions in Aron (1999) and Mills (2000). They note that elites are a small number of influential people with significant societal power, and who occupy higher positions in the organisational hierarchy. In all, three stakeholder groups participated in this study namely corporate executives (designated as 'E'), regulators (noted as ' $R$ '), and corporate governance consultants (labelled as ' $C$ '). The position, experience and knowledge of corporate governance issues of these participants were central to their participation in this study. These characteristics, in addition to their relationship with elites in different spheres of the country, were central to their selection as participants. This study involves executives from various corporate organisations listed on the Nigerian Stock Exchange (NSE). These elites (Bakre, 2007; O'Shannassy \& Leenders, 2016) not only retain influence in their corporations but also in the industry.

The sample selection follows two consecutive stages. Participants' selection initially relied on their knowledge of corporate governance, and after that, their position in the organisation. Among Nigerian companies, corporate governance decisions are the preserve of top board executives. These executives, given their positions and influence in their organisations, qualify as corporate elites (Sikka, 2017). This is consistent with prior research (Daguerre, 2013; Cardenas, 2016), where top executives were employed to investigate corporate elitist influences. It is worthy to note that corporate elites in Nigeria have extended their operating

\footnotetext{
${ }^{2}$ Collectivism indicates a preference for a tightly knit framework in society wherein individuals expect their relatives or group members to look after them in exchange for unquestioning loyalty (Hofstede et al, 2010).

${ }^{3}$ The problem in penetrating elites (see Hertz \& Imber, 1995) given the extent of power distance meant it was challenging accessing data respondents. The use of snowballing helped in minimising the effect of this limitation. Also, the sensitive nature of the research focus resulted in postponements and cancellations of scheduled interviews.
} 
locale. Increased involvement in politics, religion, and traditional institutions (see Hadani, 2012; Rivzi, 2015), among others, have reinforced their relevance.

The next sets of participants, i.e. corporate governance regulators, are director-level employees in the principal corporate governance regulatory institutions in the country. These include the Central Bank of Nigeria (CBN), Securities and Exchange Commission (SEC), Nigerian Deposit Insurance Commission (NDIC), and the NSE. The final class of participants were consultants (see also Adegbite, 2015), many of whom have previously held executive positions in publicly listed companies. This group provided perspectives on how elites take advantage of institutional voids to achieve their desired outcomes. The selection of these three categories of participants was influenced by two factors. First, the corporate governance literature in Nigeria has benefitted from the inputs of these three categories of participants (see Nakpodia et al., 2016). Second, the desire to generate broad and rich data demands the engagement of wider stakeholder groups. Table 1 presents the profiles of the participants.

Table 1: Profile of Participants

\begin{tabular}{|l|c|c|c|c|c|c|}
\hline \multirow{2}{*}{ Stakeholder Group } & \multicolumn{5}{c|}{ Career Background } & \multicolumn{2}{c|}{ Total } \\
\cline { 2 - 8 } & Law & Finance/Accounting & Economics & Others & Participants & $\%$ \\
\hline Corporate Executives & 2 & 6 & 3 & 3 & 14 & 43 \\
\hline Regulators & 3 & 4 & 1 & 3 & 11 & 33 \\
\hline Consultants & 2 & 3 & 0 & 3 & 8 & 24 \\
\hline Total & $\mathbf{7}$ & $\mathbf{1 3}$ & $\mathbf{4}$ & $\mathbf{9}$ & $\mathbf{3 3}$ & $\mathbf{1 0 0}$ \\
\hline
\end{tabular}

As part of our sampling strategy, the engagement of an appropriate number of participants is central to achieving our research objectives (Marshall et al., 2013). However, Mason (2010) maintained that the guiding principle for sample size in qualitative studies should be the concept of saturation. This demands that researchers should satisfy themselves that they have learned, and understood the phenomenon to sufficiently create knowledge. This was the primary factor in determining an appropriate sample size in this research. Thus, in this study, we conducted 33 interviews, with 21 of these interviews tape-recorded. Uche, et al. (2016) note that it is culturally challenging to record interviews in Nigeria owing to trust concerns. This lack of trust by participants meant that 12 interviews were not tape-recorded. The interviewer however made handwritten notes to capture key responses provided during the interviews. 
The data for this study was analysed utilising the qualitative content analysis (QCA) technique, which allowed the interpretation of our transcribed textual data using a systematic classification process of coding and detecting themes or patterns (Hsieh \& Shannon, 2005). Unlike the conventional (quantitative) content analysis, Schreier (2012) asserts that QCA is not constrained to frequency counts. Rather, as Mayring (2000) emphasises, it offers an opportunity to explore core themes. These features, in addition to its significant connection to interpretivist features (Flick, 2014) were central to its use in this study. This research employs the procedure in Elo \& Kyngäs (2008) to explore, classify and understand the data collected.

The first stage of our data analysis involved generating sub-categories from an open coding process. This stage ensured that key terms from the transcribed interviews were classified into much smaller content categories (Weber, 1990) to generate themes. The themes in the subcategories represent the views of participants regarding corporate governance institutions in Nigeria, as influenced by various forms of elitist interventions. These subcategories, following the second stage of analysis, produced the generic categories. The generic categories assisted in reducing the number of sub-categories by collapsing those that are similar or dissimilar into broader higher order categories (Dey, 2003). The final stage of our data analysis, i.e. the abstraction stage, helped in generating answers to the research problem (Polit \& Beck, 2012). This stage produced the main category that addresses the study's research inquiry, i.e. elitist influences on the institutional environment for corporate governance in Nigeria. We analysed data with the aid of NVivo, a qualitative data analysis software. This software assisted the generation of nodes (codes) which we compared to manually generated codes for consistency. The NVivo software not only enabled effective data management (Bazeley \& Jackson, 2013) but was also helpful in the preparation, organising and reporting of the study's findings.

\subsection{Analysis and Discussion of Findings}

Our data show that the institutional mechanisms for corporate governance in Nigeria reflect the preferences of three interrelated groups of elites, i.e. political, cultural and religious elites (see Figure 1). In this section, we analyse and discuss these findings, paying attention to the mechanisms employed by the elites, and using supporting extracts from our anonymised data (E1-E14; R1-R11; C1-C8).

\section{Figure 1: Thematic Framework for Findings}




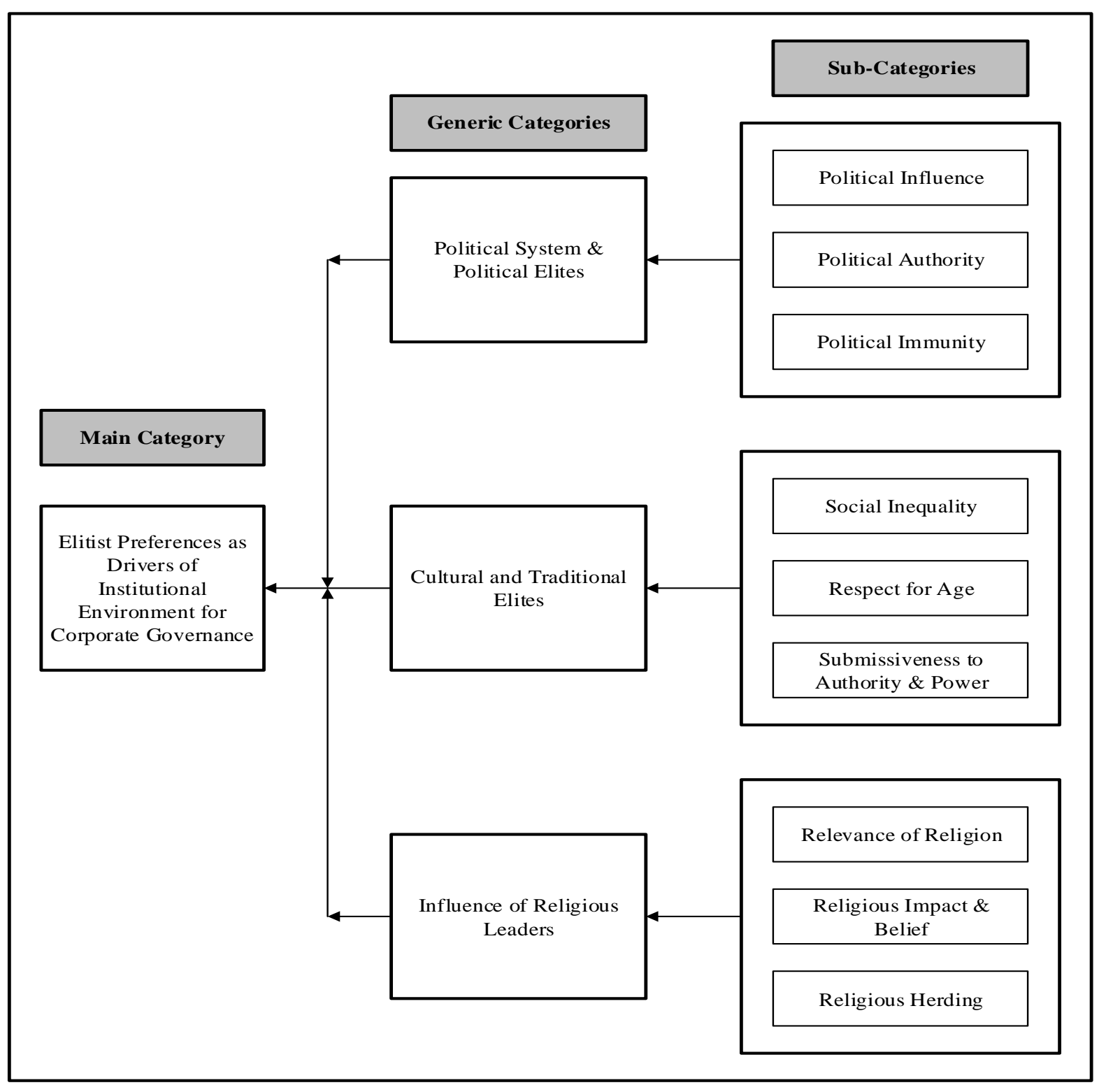

\subsection{Political Elites and Corporate Governance}

Data respondents acknowledge the link between corporate governance practice and political elites. Political elites are highly-placed political office holders (Higley and Lengyel, 2000). Our data reveal that political elites use three main influencers to retain influence on corporate governance institutions. These are political influence, political authority and political immunity. Political influence involves the interactions of various stakeholders who possess limited control over the rewards of political actors (Aplin \& Hegarty, 1980). This suggests that political influence relates to influences on political decision making. Its effects are evident among Nigerian businesses. For instance, E4 noted that; 
From my experience in the industry, the sort of influence that political office holders wield in publicly-listed companies is not healthy for the business or economic environment.

While E4 affirms that political influence is apparent in the business environment, the discharge of that influence by political elites is a source of concern. E11 also notes that;

...our political system ...is the driver of ...our problems. Take political office holders (for example); there are instances where politicians influence board composition of some corporations...This undermines the principles of corporate governance.

Comments from other respondents (R4, E5 and E7) illustrates that this is a concern prevalent among political elites. The ability of political leaders to influence organisational choices rely on the control they wield over organisational outcomes (Nahavandi, 2006), such as in the award of government contracts. The implication for corporate governance is that the possession of such influence by political elites overwhelms the capacity of corporate governance institutions to effectively monitor behaviour (Dahan, Hadani \& Schuler, 2013). Our data reveal that the possession of political influence by politicians is permitted by weak legal institutions, unlimited power, greed, societal expectations, poverty, illiteracy, and notably, the desire to preserve their social status. These elements are consistent with the 'opportunity spaces' created by institutional voids (Mair \& Marti, 2009). R5 opined that:

Politicians' desire to live up to the expectations of friends and cronies. Once you are a top politician, some public status is bestowed on you. The next thing is to ...preserve that status. Preserving that status involves engaging in (unethical) activities that conflict with corporate governance.

Whereas the desire to maintain a privileged public status may not be a problem in itself, the means of achieving and maintaining the status is often inconsistent with good corporate governance principles. Our data suggest that politicians collaborate with corporations to engage in unethical and fraudulent practices to enhance their public status (Schuchter \& Levi, 2015). The inability of citizens to scrutinise politicians (see Aplin \& Hegarty, 1980) accelerates their political influence, which subsequently produces unrestricted political authority.

Cassinelli (1961) noted that political authority relates to ordering, regulating, shaping, and determining the behaviour of human beings. These features of political authority connote control of individuals. While terms such as 'shaping' or 'determining' can be viewed positively, words such as 'ordering' and 'regulating' imply a desire to compel behaviour. Hence, political authority remains a primary concern for corporate governance. In Nigeria, for instance, Ogbeidi (2012) noted that political authority is usually exercised not necessarily for stakeholders' 
benefit, but for the personal financial benefits of politicians. This fact is corroborated in Otusanya et al. (2016) who argued that political corruption amongst legislators in Nigeria is exacerbated by the inability of regulators to apply sanctions effectively. The implication, as noted in Domadenik, Prašnikar and Svejnar (2016), is that developing democracies that lack the will to punish political corruption provide opportunity spaces for maximising political connectedness. E1 notes;

In this country, possession of political authority comes with ...benefits. (The politicians) are very rich, but you cannot identify the source of their wealth.

Regarding the above, R3, also noted that;

Our politicians enjoy the unlimited capacity to impose obligations on the people. There are virtually no opportunities for the citizens to question the authority of these politicians, especially their infractions in the area of public and corporate governance.

These comments highlight the fact that political elites engage their authority to entrench their corrupt activities (Sikka, 2017). The comments also underline the challenge encountered by regulators when investigating the corporate governance infractions committed by politicians. The political system limits the capacity of regulators to prosecute political elites (Otusanya et al., 2016). Indeed, the prospect of evading prosecution encourages the pursuit of political authority. While the influences and powers of political elites are aided by weaknesses in legal institutions (Adegbite, 2012; Ferry et al., 2017), this development has had implications for the legitimacy of political institutions. E9 stated that:

You see the way political leaders parade themselves and show off their wealth. They do this to oppress the people and remind us of their public status. (Hence) these politicians and the entire political system that brought them to power are not respected.

Legitimacy concerns, in the political domain, emerge when there are inconsistencies in the expectation of leaders and the followers thereby creating a lack of trust. As E9 notes, there is a misuse by politicians, of the authority which their positions confer on them to derive private benefits from the corporate sector. The effect on corporate governance is that policies from the government also lack legitimacy. Coglianese (2007) observed that corporate governance is becoming structured more akin to governments in certain ways. This suggests that whereas a well-run government might produce a good corporate governance system, governments lacking legitimacy may hinder the same. This challenge is worsened by the provision of immunity clauses in the country's constitution. 
Political immunity means that certain politicians (the President, Vice-President, Governors and Deputy Governors) are not accountable for their misdemeanour while in office. Consequently, interviewees identified political immunity as another area which politicians have succeeded in manipulating to their advantage. Corporate governance challenges, they claim, have been heightened by the 'legalised immunity' which politicians can access. This immunity is entrenched in Section 308 (Subsection 1) of the 1999 Nigerian Constitution. The use (and abuse) of immunity clause is widespread in countries such as Nigeria (Markovska \& Adams, 2015). Immunity 'powers' indicate that political elites are not held accountable for their actions. On the expiration of their tenure, politicians may face prosecution, but as Markovska and Adams (2015) observed, the immunity clause gives political office holders enough time to 'clean up their acts' while in office. This system of protectionism (Markovska \& Adams, 2015) ensures that politicians appoint individuals who are sympathetic to their cause. Thus, at the completion of their tenure, these appointees work for them and conceal their acts. This underscores how political immunity reinforces the influence and authority wielded by political elites on corporations. As Adegbite et al. (2012) noted, the Nigerian political system reflects its high incidence of corruption, given that Nigeria has typically lacked the institutional capacity to tackle political corruption. They further noted that politicians continuously seek financial support from corporations. This reinforces public-private corruption (supply and demand-side corruption), and it is within this climate that corporate governance finds expression.

In line with the aforementioned, $\mathrm{Wu}(2005)$ affirmed that the political environment in a country determines the extent to which key political actors can influence policy outcomes. This influence can be extended to create another form of immunity, i.e. the implied immunity, which manifests when immunity extends beyond politicians. This happens when political elites influence corporate governance, by having their family members, cronies (O'Sullivan, 2000) and political bagmen (i.e. individuals that collect financial contributions from businesses on behalf of politicians) (see Neu et al., 2013) appointed to corporate boards. Their cronies, representatives, relations and political bagmen are immune from prosecution, as they take advantage of their relationship with political elites. This escalates the challenges confronting the functionality of corporate governance institutions and promotes undesired isomorphic tendencies in the institutional environment. Such isomorphic characteristics strengthen the influence and authority of political elites and provide a system for entrenching political immunity. $\mathrm{C} 1$ acknowledges this concern; 
What type of corporate governance do you expect when some people cannot be held accountable for their illegal acts because of the position they hold? ...political immunity does not connect with (the ideas of) corporate governance.

\subsection{Cultural/Traditional Elites and Corporate Governance}

In the institutionalism-based corporate governance literature, evidence (Haniffa \& Cooke 2002, Licht, Goldschmidt \& Schwartz, 2005) indicate that culture influences corporate governance. Similar conclusions are reported in Nigeria. Oghojafor et al. (2012), for instance, described the relationship between corporate governance and national culture as 'Siamese twins.' Similarly, the majority of the participants also agreed that culture has significant implications for corporate governance in Nigeria. For example, C3 stated that 'you cannot separate people from their culture,' while R1 noted that 'culture ...plays a very significant role in all that we (Nigerians) do.' Related to the effect of culture on corporate governance, is the influence of cultural elites comprising of traditional rulers, community elders and other cultural leaders. As with political elites, our data shows that cultural elites rely on three factors to influence corporate governance institutions. These are social status inequality, respect for age and submissiveness to authority.

On social status inequality, the preservation of social status is crucial to Nigerians. Ikoku (2013) admitted that in the Nigerian society, there is an opportunistic assertion that individuals are not equal. As a result, subordinates expect to be 'told what to do,' while the boss is permitted to exhibit autocratic behaviours. This is described as 'ascription' in Trompennars and HampdenTurner (2004) culture framework, suggesting that in such societies, power, title and position matter, and these 'privileges' define behaviour. These privileges facilitate institutional voids that allow for corruption (Sikka, 2017). Furthermore, it provides the incentive for reconfiguring existing (corrupt) networks towards the desired goal (Neu et al., 2013). This is because those that possess these privileges acquire added capacity to act with less restraint, compared to those without them. Thus, the possession of these privileges enhances social status. E3 notes that;

...when (individuals suggest) that fingers are not equal, they (imply) that human beings are not equal. Unfortunately, that perception influences their action.

C2 also stated that;

...Traditional rulers see themselves as direct descendants of the supreme God. Their actions reflect this understanding. Even when they are involved in (corporate) relationships, they expect that same privilege. 
The above comment denotes social status inequality, i.e. recognising the authority and power of certain people relative to the rest of society. In contrast, corporate governance demands that stakeholders be treated fairly and equitably. However, the problem with this notion, as noted in Omololu (2007), is that legal concepts such as the rule of law are redefined to accommodate the excesses of the privileged few, owing to weak enforcement of laws (Khanna and Palepu, 2000). This is also evident in R2's comment;

The quality of corporate governance in a country is determined by the efficacy of (its regulation). However, in a country where rules are obeyed by the less-privileged but ...flouted by the rich and well-connected, this would affect the corporate governance system.

The contribution by $\mathrm{R} 2$ reinforces the centrality of the regulatory/legal system to the emergence of a robust corporate governance framework. The effectiveness of existing regulation not only impacts corporate governance but acts to regulate the behaviour of important stakeholders (North, 1990). Neu et al. (2013) noted that the relatively low rate of corruption in developed economies ties with the robustness inherent in the institutions operating in countries that had created an effective reward-punishment mechanism. However, good corporate governance is impaired in contexts where existing regulations are subject to various interpretations based on social status (wealth, political affinity).

The social status inequality problem is exacerbated by 'respect for age. On this, respondents noted that another explanation for the undesirable impact of culture on corporate governance stems from the respect accorded elderly stakeholders (e.g. executives) in corporate environments. Consequently, their actions and inactions are usually not questioned, in observance of implied cultural beliefs. E9 noted this view;

I have witnessed a board meeting where there was palpable respect for elders on the board. It was evident that some executives were conscious of the age of other executives hence they could not question comments from the 'elders'.

This belief system is prevalent in both public and private entities in Nigeria. R1 agrees that 'our culture requires that we respect elders, ' hence an attempt to question an older executive, for instance, by a younger person is deemed 'disrespectful.' While this reinforces power distance (see Hofstede et al. 2010), Conton (1964) reported that this problem is prevalent in many African countries, where they have much respect for age, such that, the older you are, the more respect you earn. This attitude increases the possibility of exempting older people from liabilities and penalties. To further highlight the relevance of age, an Ibo (one of the three 
largest ethnic groups in Nigeria) adage claims that 'paying attention and listening to an elderly person is like consulting an oracle.' While this equates an older adult to an Oracle (god), it stresses the cultural challenges in confronting an elderly executive when infractions are apparent. E5 admits this concern;

As an executive, there is the tendency to be mindful of age when relating with people in many corporate boards in (Nigeria). Often, older people, by their age, bring undue pressure on younger (colleagues) thereby restricting their objectivity in (corporate) decision making.

E5's account suggests that corporate governance in Nigeria responds to the dominant cultural paradigm in many parts of the country. In Nigeria, the elderly are highly respected and perceived as a leader. The preceding explains why prior research suggests the preference for older directors on corporate boards in Nigeria (Adegbite, 2015).

Notwithstanding the respect accorded to age in the Nigerian society, individuals with power and authority attract similar esteem. As such, the third influence linked to cultural elites is submissiveness to power and authority. E8 remarked that;

...We defer to authority. For instance, if you have a traditional ruler as the chairman of a Board, would you argue with him?

The connection which E8 established between corporate executives and traditional rulers offer an intriguing proposition. As traditional rulers were historically known to oversee activities in their local domain, their engagement by the British during the colonial era reinforced their societal relevance. ${ }^{4} \mathrm{E} 3$ observed that traditional rulers are regarded as gods in their domain hence their decisions or authority are not usually questionable. Their authority is evident in the political environment. The 'esteem' accorded to traditional rulers inform their engagement across different economic spheres. For instance, some serve as chairmen of corporate boards, while virtually all universities in Nigeria appoint traditional rulers as chancellors. Regardless of these assignments, their status as traditional rulers attracts reverence, even when they err. E3 illustrates the effect on corporate governance;

...when that mentality is brought into a corporate setting, the chairman or the CEO can have a superiority complex or even a god-complex, such that the person is unable

\footnotetext{
${ }^{4}$ British colonialists introduced the indirect rule system, which had traditional rulers at its foundation. Traditional rulers acquire their status through succession hence their authority is often rooted in traditions and customs
} 
to ...obey corporate governance codes because, as the CEO or chairman, he sees himself as a god.

The effect of this development was noted in Warren (1996), asserting that authority compels a surrender of judgement by those subject to that authority. However, given Solomon's (2013) description of corporate governance as a checks and balance mechanism, the effect of the misapplication of authority in Nigeria on corporate governance is problematic.

\subsection{Religious Elites and Corporate Governance}

As shown in Figure 1, a generic category that emerged from the coding of participants' responses is the increasing influence of religious leaders. Despite the limited literature examining the impact of religion on corporate governance, Barro and McCleary (2003) and McCleary (2008) contend that religion is essential to economic development. This is consistent with Kempf Jr's (2008) observation, noting that religious factors may contribute to the success (or otherwise) of corporate governance. However, Guiso, Sapienza and Zingales (2003) note that much of the existing evidence regarding the impact of religion builds on cross-country studies wherein the impact is affected by variations in institutional contexts.

The lack of attention to religious elites in the institutional theory scholarship is because developed economies provide the studied settings. Findings in Norris and Inglehart (2011) reveal a decrease in the religiosity index between 1947 and 2001 in many developed economies; hence the generality of literature has considerably neglected the role of religious elites in those climes. Norris and Inglehart (2011) added that following the economic buoyancy in developed countries, the religiosity of its citizens has dipped. Kuran (2009) and Stastna (2013) suggested that people overlook religion as they become wealthy. In contrast, many developing countries are looking to religion for hopes of economic emancipation. Adi (2005), for example, stated that the belief in the supernatural or spiritual realities is central to the worldview of Nigerians. Adamo (2001) added that the richest and the most important heritage of Africa is religion, as it permeates the entire life of the African people, shaping their cultural, social, political and economic activities. The views by Adamo (2001) and Adi (2005) have stimulated the emergence of religious elites in Nigeria.

Countries with a dominant religion (e.g. Saudi Arabia) are likely to have many of their policies influenced by religion. Thus, when E2 comments that religion is crucial to societies, such assertions are informed by practices in the respondent's environment. This reasoning informed the generality of participant's responses. There are three main influencers, also used by 
religious elites to retain influence on corporate governance. These are the relevance of religion, religious impact and belief, and lastly, religious herding. With regards to the relevance of religion, most participants agreed that religion is crucial to corporate governance in Nigeria. They note that religious principles link with corporate governance practice E9 explains that; ...religion plays a significant role (in corporate governance). Religion preaches fairness, ethics and (...). Corporate governance is an offshoot of what religion (emphasises).

As religion plays a significant role in the country, Nigeria is witnessing an increasing influence of religious leaders in corporate governance. This has further enhanced the public profiling of religious organisations and their leaders. In supporting E9 above, R3 notes that;

In this country, the issue of religion is fundamental (to) every area of our lives. In politics, in business. Many (religious leaders) are aware of this. Some (religious leaders) take undue advantage of this opportunity.

In the context of E9 and R3's comments, it is appropriate to expect that the values associated with religion should spur the emergence of a robust corporate governance system. Grullon, Kanatas and Weston (2009) agreed that religion should provide a developmental path for corporate governance in developing economies. However, this expectation is challenged by religious elites as noted by $\mathrm{R} 3$. While there are indications that devotees seek to model their behaviour in line with those of their leaders (Abioje, 2005), it raises questions regarding how religious impact and belief system affect corporate governance. Mainly, how do the principles of religion such as ethics and morality promote corporate governance in Nigeria? In addressing this question, E6 noted that;

Religion preaches fairness and ethics... To my understanding, this is what corporate governance typifies. The (principles of) religion affects corporate governance positively.

Similarly, C3 also stated that;

Every religion is guided by the golden rule which is doing unto others what you expect them to do to you. Corporate governance is about aligning the interests of one party to those of another party.

The responses of E6 and C3 indicate a positive relationship between religion and corporate governance, as their comments imply that the underlying drivers of religion can facilitate the emergence of a robust corporate governance. These reactions are important to corporate governance in Nigeria, given the growing popularity of religion in the country, as highlighted by $\mathrm{C} 1$; 
...we are very religious in this country. Some of the churches and the mosques are very strong. They have much impact on the people.

The above comment is reflected in participant's religious affiliations as they are either Christians or Muslims. However, while the majority of participants suggest that religion impacts governance, a minority of the participants argued that religion does not influence corporate governance practice in Nigeria. R1, for example, commented that;

I do not think so because the rules are clear. The code is explicitly clear, so religion does not necessarily have any input in determining the extent of compliance with corporate governance codes.

On R1's view, Kuran (2009) takes a similar position but acknowledges that country specificities could compel different outcomes (see also, Guiso et al., 2003, Grullon et al., 2009). Nonetheless, the majority of respondents highlighted instances where religious leaders exerted undue influence in shaping corporate governance outcomes, including board appointments, corporate investment decisions, amongst others. E7 notes;

Religious leaders have an influence on their followers, including board members, which does filter into boardroom decisions.

The last factor used by religious elites is religious herding. The influence and power of religious leaders are significant factors that have stimulated the surge in religiosity among Nigerians. $85 \%$ of Nigerians trust their religious leaders and would be willing to give them more power (Ferrett, 2005). Indeed, there is an increasing relationship between religious and political elites, with politicians enlisting the support of religious leaders in accessing devotees (electorates). This relationship has attracted criticism because it fosters corruption. While Sampson (2014) argued that the patronage of religion by politicians is a tool for propaganda and political advantage, Markovska and Adams (2015) state that corrupt elites engage religion to incite the poor and illiterate masses (devotees) to achieve their selfish religious and political ambitions. The association with politicians have provided opportunities for religious leaders to take advantage of institutional voids such as failure to comply with government policies (see Ferrett, 2005). Moreover, as leaders, they have employed various approaches to shape the consciousness of Nigerians, thereby strengthening their growing relevance. R4 states that this growing influence has meant that; 
Religious leaders have become almost infallible. Whatever they say has to be the rule without question. In fact, many people have lost their rationality. They do not question their (religious leaders). They honour the words of their religious leaders more than the laws of the land.

The reverence accorded to religious leaders in Nigeria has helped them secure privileged economic positions with access to significant financial resources, which strengthens their societal profile. $\mathrm{C} 1$ admits the considerable financial resources of religious leaders;

You know, (some of) our religious leaders are amongst the richest in the world. Some own private jets. One of the best universities in the country today is owned by a (religious leader). Many of them hold directorships in listed companies with substantial shareholding. Their political relevance is on the increase. In fact, any serious political aspirant must visit them before elections, to obtain the votes of (devotees).

The above comment by $\mathrm{C} 1$ highlights a significant concern, i.e. a herd mentality. Abioje (2005) stated that many Nigerians are conditioned by what they learn from their religious leaders. The implication for corporate governance is that as these leaders (or their devotees) occupy executive positions in Nigerian corporations, the companies, in the long run, reflect the preferences of these religious elites. This was evident in R2's comment;

You have some religious leaders that are chairmen of organisations in this country. Some others are appointed to corporate boards. When you consider the unethical practices that some (religious organisations) are accused of, you wonder how their leaders will discharge their responsibilities in a corporate environment.

This practice gradually becomes a societal norm as the lure of religion intensifies. Participants also affirm that the current poverty level in the country had reinforced the herd mentality and boosted the rise in the influence of religious elites. C3 observed that religious leaders understand that poverty and economic deprivation stimulates the search for religious empowerment. Consequently, these leaders have become a beacon of hope for devotees, and also, a possible avenue for economic liberation. R4 shared these concerns;

I think the poor economic environment has allowed religion to thrive such that religious leaders have become increasingly significant in our social lives. .... Non-existent checks and balances ensure that corporate governance remains weak, especially in organisations where religious leaders are in charge.

While most interviewees reported concerns in the conduct of religious elites, Abioje (2005) equally questioned the morality and ethical stance of religious leaders, stating that they exert negative influences on their devotees. Sampson (2014) also informed that religion has not 
generated the puritanical disposition or abhorrence for unjust behaviour among adherents that would have served as a basis for good corporate governance. Therefore, over time, devotees begin to exhibit similar traits as their leaders thus institutionalising the herd behaviour. This behaviour subsequently produces a group conduct that is inconsistent with the accountability principles underpinning corporate governance (see Abioje, 2005, 2011).

\subsection{Further Discussions}

Our analysis highlights the difficulty in restricting elitist influences on institutions in Nigeria to a specific elite group. Various elitist groups influences institutions (see Higley \& Lengyel, 2000; Rizvi, 2015) directly or indirectly. For instance, while the activities of religious and cultural elites are felt more in the social (cultural and religious) domain, the peculiarity of the institutional environment in Nigeria (given its low economic development) indicates that corporations reflect the dominant traits in the society (Bottomore, 2006; Cardenas, 2016). This shows how elites interrelate to reinforce their influence on social and corporate institutions (Catchpowle \& Smyth, 2016). For example, our data suggested that religious leaders not only command attention in their religious domains but can assume executive positions in companies. Their recruitment to executive positions is sponsored by their devotees, who are often corporate elites. It is noteworthy that the distinctiveness of the researched context has highlighted elites (traditional and religious) whose influence is as important as those of entrepreneurs.

However, unlike traditional and religious elites, our data indicate that political elitism in Nigeria bears considerable influences that overwhelm those of other elitist groups. The locus of opportunity space accessible by political elites is extensive given the (mis)conceptions regarding democracy and economic development (Ferry et al., 2017). The manipulation of state machinery is largely possible by politicians. Inyang (2009) suggested that the state of institutions reflects government (mostly politicians) preferences. Indeed, the little or no attention paid to the strengthening of institutional elements is intended to pave the way for institutional voids, which permit the perpetuation of corruption by elites. The overwhelming influence of political elites explains the democratic approach in Nigeria. For instance, while the appointment of traditional rulers (i.e. cultural elites) is the preserve of residents in the local communities, their appointment must be ratified by political office holders. This institutional void weakens checks and balances, enhances the political authority and political influence as revealed by our data. More importantly, it undermines the 'controls' against political corruption (Wu, 2005). 
Warren (2003) noted that political and social elements are becoming increasingly influential than economic forces in shaping corporate behaviour. Forbes and Watson (1993) and Woodward, Edwards and Birkin (2001) also acknowledged that corporate executives attempt to 'set the agenda' to manipulate societal opinion to secure a favourable view of corporate activity. As a result, the distinction between social institutions and corporate governance institutions is weak as both sets of institutions not only react to but aim to satisfy the preferences of the same elitist groups. In fact, a review of the challenges confronting corporate governance in Nigeria by Adegbite and Nakajima (2011) pointed at underlying weak social institutions. Udama (2013) and Okafor (2013) also argued that the pervasive corruption in the Nigerian social sphere not only has an adverse impact on the political system but has equally stimulated corporate corruption.

Furthermore, the literature has identified the existence of a symbiotic relationship between elites and institutions (Ferry et al., 2017). Higley and Lenygel (2000), for example, noted that elites shape institutions, but institutional mechanisms influence how elites compete and emerge. Our study, however, presents a different view, i.e. the emergence of elites is not necessarily linked to institutions. Elites can, however, invent institutional voids that may be perceived or misunderstood by stakeholders as the 'new institutions'. In developed economies, for instance, institutions are robust such that the demise of an elite does not result in the disappearance of that institution. In contrast, social institutions in weak institutional contexts typically reflect the preferences of an elitist group such that the death of a member of that group can upset the continued relevance of that institution. Rahaman, Everett and Neu (2007) establish how the instrumentality of accounting (a possible proxy for the institutional element) was overwhelmed by elitist biases. This informs why it is possible for firms in developed economies to exist over the long-term whereas such longevity is a rarity in developing economies. Similar examples are evident in traditional and religious institutions.

The preceding discussions further reinforce the view that elitist influence bears significant implications for the permanency characteristic of institutions (Dulbecco \& Renard, 2003, Dacin \& Dacin, 2008). In recognition of these issues, institutional theorising has benefitted from deinstitutionalisation (Oliver, 1992, Maguire \& Hardy, 2009). Deinstitutionalisation, according to Oliver (1992), denotes the erosion or discontinuation of an institutionalised organisational activity or practice. It entails the process wherein institutions become weak and subsequently disappear (Scott, 2004), or rejected and later abandoned (Dacin \& Dacin, 2008). This 
possibility emphasises the importance of acknowledging the broader context of institutions, as the weakening and subsequent disappearance of a set of beliefs are likely to stimulate the arrival of new ones (Gilmore \& Sillince, 2014). Our study suggests that elites impact the process of institutionalisation and deinstitutionalisation (see also Adegbite and Nakajima, 2012). This indicates that institutional permanence is shaped by elites, particularly in weak business environments.

\subsection{Contributions}

The extant literature on institutional theory has explored the capacity of institutions to constrain the behaviour of elites (North, 1990, Scott, 2014); however, contexts where institutions are incapable of achieving such expectation have attracted limited attention. This paper contributes to the nascent literature on corporate elitist influence by generating nuanced insights from a weak institutional context to aid our understanding of the role of elites in corporate governance. Our data indicate that elites influence institutional frameworks of corporate governance in Nigeria, thereby challenging North's (1990) proposition. Our study reveals how the activities of three classes of elite, i.e. political elites, cultural elites and religious elites, have undermined the effectiveness of corporate governance in the country.

Our discussions not only provide caution to the widely held assumption in the literature that institutions act as a check on the behaviour of economic actors (North, 1990), we also explore the institutional void and elites' narratives to highlight possible deviations from the mainstream view of institutions. Our data show that institutional voids drive the emergence of elites and facilitate systemic corporate corruption. This study highlights the implications of elitist influences on corporate governance institutions in Nigeria, contending that the influence exerted by elites challenges institutional resilience. This affirms that, over a relatively short time, human intervention can motivate institutional changes (Lipset, 1960). This acts as instruments of deinstitutionalisation (Oliver, 1992; Maguire \& Hardy, 2009) and undermines the institutional permanence argument (Dacin \& Dacin, 2008). In sum, we further make two important contributions to the literature.

First, the institutional theory literature on corporate governance has focused on institutional frames which assume that the dominant variants of institutions in varieties of capitalism (see Giddens, 1984; Aguilera \& Jackson, 2003; Judge et al., 2008) dictate the state of the institutional environment for corporate governance. However, as our study shows, the activities 
of elites in the political, cultural and religious domains impact existing institutions in Nigeria. This evidence contradicts the dominant theme in the institutionalism-based literature that emphasises the capacity of institutions to constrain agent (or elite) behaviour. Our study, however, indicates that systemic opportunity spaces, i.e. institutional voids, accelerate the ability of elites to influence institutions. This finding is empirically relevant to the corporate governance debate in the majority of sub-Saharan Africa and other weak institutional settings.

Second, this research has generated important insights regarding the connections between religion, elites and corporate governance. Whereas political and cultural elites have attracted attention amongst scholars, the literature examining religious elites is extremely scarce. The emergence and the subsequent influence wielded by elites over corporate choices are explained by the herding power of religion notably in high religiosity environments. Our study has indicated that the degree of religiosity in society, and the concerns bordering on social security and poverty, inform and strengthen the presence and influence of religious elites. The implication for corporate governance is that in environments where there are opportunity spaces to engage in unethical practices by elites (such as corruption among religious leaders), devotees (i.e. stakeholders) are gradually motivated to operate by the (unethical) ideals of their religious leaders. This finding extends the scope of 'actors' discussed in the institutionalism literature, as this study demonstrates that religious elites can provoke institutional changes. Ahrens and Ferry (2016) affirm the importance of emotions (consistent with religion) in institutional change.

In conclusion, this paper highlights the elitist influences on institutions that affect corporate governance. As Khan (2012) notes, this area of scholarship has attracted little attention in corporate governance research and the institutionalism-based literature. While drawing insights from Nigeria, we show that the institutional environment for corporate governance reflects elitist influences. As a result, we note that institutions of corporate governance represent a variable whose functionality relies on other conditions (in this case, elites).

Our discussions present some implications for practice. Widespread corruption, aided by institutional voids, disrupts the institutions that support good corporate governance. The ineffectiveness of institutions in developing economies is due, to a large extent, to the weak enforcement mechanism, smoothed by institutional voids. The existence of robust institutions in the advanced economies informs its strong enforcement strategies. We, therefore, propose 
that policy makers in Nigeria must improve the enforcement mechanisms for institutions of corporate governance to reduce the powers and influence wielded by elites. Also, there is the need to provide more resources towards strengthening the power of regulators and enforcement agents while minimising the overbearing influence of elites over regulators.

\subsection{Areas for Further Research}

The findings in this paper provide opportunities for further research. Engaging Nigeria as a proxy for developing economies, we provide empirical insights into the shapers of the institutional environment for corporate governance. This paper acknowledges that elitist influence restricts the degree to which institutional elements can check the behaviour of stakeholders. This outcome is however linked to variations in institutional effectiveness across different contexts, as these differences account for the emergence of institutional voids. Therefore, future research can advance this area of scholarship by undertaking similar investigations in other business environments in both developing and developed economies. This will not only address Khan's (2012) concerns regarding the incompleteness of literature examining the role of 'elites' in business environments but will facilitate the identification of the specific intervention and influence of elites regarding corporate governance. This area of scholarship is under-researched.

Furthermore, the findings from our study relied on insights provided by participants drawn from organisations listed on the NSE and key corporate regulators in the country. While this questions the generalizability of the study outcomes, participants, however, included consultants who have undertaken various corporate governance consulting responsibilities in companies, not listed on the NSE. Thus, their contributions do reflect broad practices. Nonetheless, the largely informal nature of the institutional environment in developing economies has intensified the relevance of two other forms of businesses, i.e. small and medium enterprises (SMEs) and public (government) corporations. This study did not engage corporate elites in these business organisations. We suggest that the extant literature will benefit from the examination of the views of stakeholders in these forms of business organisations. This would strengthen existing evidence regarding the relationship between corporate governance and elites. 
Additionally, our evidence highlights the peculiarity of the institutional environments in developing economies. Given this peculiarity, further insights into the institutionalism-based literature, especially those addressing institutional concerns amongst developing economies, are necessary. Our study indicates that existing institutions have neither succeeded in narrowing institutional voids nor limit the incidence of corruption. Thus, we propose that future studies should explore complementary strategies for 'controlling' the influence of elites' other than those proposed in the institutionalism-based literature (i.e. institutions). This is because the nature of the institutional environment in developing economies demand the adoption of a different approach to addressing its institution-inspired problems. Importantly, this study has demonstrated that just as political, social, economic, and legal forms of institutionalisation have

gained traction over the years in corporate governance research, the impact of elites on institutions deserves similar attention.

\section{References}

Abioje, P. O. (2005). A critical view of the influence of christian leadership in Nigeria today. Journal of Religion and African Culture, 1(1), 1-17.

Abioje, P. O. (2011). A critique of commercialization of religions in Nigeria via the mass media. Ilorin Journal of Religious Studies, 1(2), 57-80.

Abioje, P. O. (2015). Christianity in contemporary African religious space. In C. M. J. Medine, I. S. Aderibigbe \& H. D. Seibel (Eds.), Contemporary Perspectives on 
Religions in Africa and the African Diaspora (pp. 79-99). New York, NY: Palgrave Macmillan.

Acemoglu, D., \& Robinson, J. A. (2008). Persistence of power, elites, and institutions. The American Economic Review, 98(1), 267-293.

Adamo, D. (2001). African American heritage. Eugene, Oregon: Wipf and Stock Publishers. Adegbite, E. (2012). Corporate governance regulation in Nigeria. Corporate Governance, 12(2), 257-276.

Adegbite, E. (2015). Good corporate governance in Nigeria: Antecedents, propositions and peculiarities. International Business Review, 24(2): 319-330.

Adegbite, E., \& Nakajima, C. (2011). Institutional determinants of good corporate governance: The case of Nigeria. In E. Hutson, R. Sinkovics \& J. Berrill (Eds.), FirmLevel Internationalisation, Regionalism and Globalisation (pp. 379-396). London: Palgrave Macmillan.

Adegbite, E. and Nakajima, C. (2012) Institutions and Institutional Maintenance: Implications for Understanding and Theorizing Corporate Governance in Developing Economies. International Studies of Management and Organization, 42 (3), 69-88.

Adegbite, E., Amaeshi, K. \& Amao, O. (2012). The politics of shareholder activism in Nigeria. Journal of Business Ethics, 105(3): 389-402.

Adegbite, E., Amaeshi, K., \& Nakajima, C. (2013). Multiple influences on corporate governance practice in Nigeria: Agents, strategies and implications. International Business Review, 22(3), 524-538.

Adi, B. C. (2005). The moral economy and the problem of accumulation in Africa: how the IFI's can help. West Africa Review. Issue 7. Retrieved September 12, 2016, from http://papers.ssrn.com/sol3/papers.cfm?abstract_id=885803

Aguilera, R. V., \& Jackson, G. (2003). The cross-national diversity of corporate governance: Dimensions and determinants. Academy of Management Review, 28(3), 447-465.

Aguilera, R. V., \& Jackson, G. (2010). Comparative and international corporate governance. The Academy of Management Annals, 4(1), 485-556.

Ahrens, T., \& Ferry, L. (2015). Newcastle City Council and the grassroots: accountability and budgeting under austerity. Accounting, Auditing \& Accountability Journal, 28(6), 909-933.

Ahrens, T., \& Ferry, L. (2016). Institutional entrepreneurship, practice memory, and cultural memory: Choice and creativity in the pursuit of endogenous change of local authority budgeting. Management Accounting Research.

Ahunwan, B. (2002). Corporate governance in Nigeria. Journal of Business Ethics, 37(3), 269-287.

Aidt, T. S. (2003). Economic analysis of corruption: a survey. The Economic Journal, 113(491), F632-F652.

Amaeshi, K., Adegbite, E. and Rajwani, T. (2016) Corporate social responsibility in challenging and non-enabling institutional contexts do institutional voids matter? Journal of Business Ethics, 134 (1), pp. 135-153

Aplin, J. C., \& Hegarty, C. H. (1980). Political influence: strategies employed by organizations to impact legislations in business and economic matters. Academy of Management Journal, 23(3), 438-450.

Aron, R. (1999). Main currents in sociological thought (Vol. II). London, UK: Transaction Publishers.

Bakre, O. M. (2007). The unethical practices of Accountants and Auditors and the compromising stance of professional bodies in the corporate world: Evidence from corporate Nigeria. Accounting Forum, 31, 277-303. 
Barro, R. J., \& McCleary, R. (2003). Religion and economic growth across countries. American Sociological Review, 68(5), 760-781.

Bazeley, P., \& Jackson, K. (2013). Qualitative data analysis with NVivo. London: Sage Publications Limited.

Bottomore, T. (2006). Elites and society (2nd ed.). London: Taylor \& Francis.

Bryman, A. (2015). Social research methods (5th ed.). Oxford: Oxford University Press.

Cadbury, A. (1992). Report of the committee on the financial aspects of corporate governance (Vol. 1). London, UK: Gee.

Cárdenas, J. (2016). Why do corporate elites form cohesive networks in some countries, and do not in others? Cross-national analysis of corporate elite networks in Latin America. International Sociology, 31(3), 341-363.

Caron, M. I., Ficici, A., \& Richter, C. L. (2012). The influence of corruption on corporate governance standards: Shared characteristics of rapidly developing economies. Emerging Markets Journal, 2(1), 21-37.

Cassinelli, C. (1961). Political authority: its exercise and possession. The Western Political Quarterly, XIV, 635-646.

Catchpowle, L., \& Smyth, S. (2016). Accounting and social movements: An exploration of critical accounting praxis. Accounting Forum, 40(3), 220-234.

Coglianese, C. (2007). Legitimacy and corporate governance. Delaware Journal of Corporate Law, 32, 159-167.

Conton, W. F. (1964). The African. Harlow: Heinemann Educational Books.

Corbetta, P. (2003). Social research: theory, methods and techniques. London: Sage.

Dacin, M. T., \& Dacin, P. A. (2008). Traditions as institutionalized practice: implications for deinstitutionalization. In R. Greenwood, C. Oliver, K. Sahlin \& R. Suddaby (Eds.), The Sage Handbook of Organizational Institutionalism (Vol. 327-352). London: Sage.

Daguerre, A. (2013). New corporate elites and the erosion of the Keynesian social compact. Work, Employment \& Society, 28(2), 323-334.

Dahan, N. M., Hadani, M., \& Schuler, D. A. (2013). The governance challenges of corporate political activity. Business \& Society, 52(3), 365-387.

Davis, G. F. (2005). New directions in corporate governance. Annual review of sociology, 31, 143-162.

Denscombe, M. (2010). The Good Research Guide: For Small-Scale Social Research Projects: for small-scale social research projects. New York: McGraw-Hill Education.

Dey, I. (2003). Qualitative data analysis: A user-friendly guide for social scientists: Routledge.

DiMaggio, P. (1988). Interest and agency in institutional theory. In L. G. Zucker (Ed.), Institutional Patterns and Organizations: Culture and Environment. Cambridge, MA: Ballinger.

Domadenik, P., Prašnikar, J., \& Svejnar, J. (2016). Political connectedness, corporate governance, and firm performance. Journal of Business Ethics, 139(2), 411-428.

Domhoff, G. W. (1990). The Power Elite and the State: How Policy is made in America. New York, NY: Aldine De Gruyter.

Dulbecco, P., \& Renard, M.-F. (2003). Permanency and flexibility of institutions: the role of decentralization in Chinese economic reforms. The Review of Austrian Economics, 16(4), 327-346.

Easterby-Smith, M., Thorpe, R., \& Jackson, P. (2012). Management research. London: Sage.

Egbe, I., Adegbite, E., \& Yekini, C. O. (2017). The influence of multinational enterprises on subsidiaries: context matters. Accounting, Auditing \& Accountability Journal, Forthcoming. 
Elo, S., \& Kyngäs, H. (2008). The qualitative content analysis process. Journal of Advanced Nursing, 62(1), 107-115.

Everett, J., Neu, D., \& Rahaman, A. S. (2007). Accounting and the global fight against corruption. Accounting, Organizations and Society, 32(6), 513-542.

Fainshmidt, S., Judge, W. Q., Aguilera, R. V., \& Smith, A. (2016). Varieties of institutional systems: A contextual taxonomy of understudied countries. Journal of World Business. Forthcoming.

Ferrett, G. (2005). Africans trust religious leaders. Retrieved February 24, 2017, from http://news.bbc.co.uk/1/hi/world/africa/4246754.stm

Ferry, L., Zakaria, Z., Zakaria, Z., \& Slack, R. (2017). Framing public governance in Malaysia: Rhetorical appeals through accrual accounting. Accounting Forum.

Filatotchev, I., Jackson, G., \& Nakajima, C. (2013). Corporate governance and national institutions: a review and emerging research agenda. Asia Pacific Journal of Management, 30(4), 965-986.

Flick, U. (2014). An introduction to qualitative research. London: Sage.

Forbes, W., \& Watson, R. (1993). Managerial remuneration and corporate governance: A review of the issues, evidence and Cadbury committee proposals. Accounting and Business Research, 23(sup1), 331-338.

Giddens, A. (1984). The constitution of society: Outline of the theory of structuration. Cambridge: Polity.

Gilmore, S., \& Sillince, J. (2014). Institutional theory and change: the deinstitutionalisation of sports science at Club X. Journal of Organizational Change Management, 27(2), 314-330.

Grullon, G., Kanatas, G., \& Weston, J. (2009). Religion and corporate (mis) behavior. Retrieved March 23, 2017, from http://papers.ssrn.com/sol3/papers.cfm?abstract_id=1472118

Guiso, L., Sapienza, P., \& Zingales, L. (2003). People's opium? Religion and economic attitudes. Journal of Monetary Economics, 50(1), 225-282.

Hadani, M. (2012). Institutional ownership monitoring and corporate political activity: Governance implications. Journal of Business Research, 65(7), 944-950.

Haniffa, R. M., \& Cooke, T. E. (2002). Culture, corporate governance and disclosure in Malaysian corporations. Abacus, 38(3), 317-349.

Hertz, R., \& Imber, J. B. (1995). Studying elites using qualitative methods. London: SAGE Publications.

Higley, J., \& Lengyel, G. (2000). Elites after state socialism: theories and analysis. Maryland, US: Rowman \& Littlefield.

Hodgson, G. M. (2006). What are institutions? Journal of Economic Issues, XL(1), 1-25.

Hofstede, G., Hofstede, G. J., \& Minkov, M. (2010). Cultures and organizations: software of the mind (3rd ed.). New York: McGraw Hill.

Hoskisson, R. E., Eden, L., Lau, C. M., \& Wright, M. (2000). Strategy in emerging economies. Academy of Management Journal, 43(3), 249-267.

Hsieh, H.-F., \& Shannon, S. E. (2005). Three approaches to qualitative content analysis. Qualitative Health Research, 15(9), 1277-1288.

Ikoku, S. G. (2013). The role of the individual in history. In A. Akinsanya \& J. A. Ayoade (Eds.), An introduction to political science in Nigeria. Lanham, Maryland: University Press of America.

Inyang, B. J. (2009). Nurturing corporate governance system: the emerging trends in Nigeria. Journal of Business Systems, Governance and Ethics, 4(2), 1-13. 
Jackson, G. (2010). Actors and institutions. In G. Morgan, J. L. Campbell, C. Crouch, O. K. Perdersen, \& R. Whitley (Eds.), Oxford Handbook of Comparative Institutional Analysis (pp. 63-86). Oxford, UK: Oxford University Press.

Jain, A. K. (2001). Corruption: a review. Journal of Economic Surveys, 15(1), 71-121.

Jensen, M. C., \& Meckling, W. H. (1976). Theory of the firm: managerial behavior, agency costs and ownership structure. Journal of Financial Economics, 3(4), 305-360.

Judge, W. Q., Douglas, T. J., \& Kutan, A. M. (2008). Institutional antecedents of corporate governance legitimacy. Journal of Management, 34(4), 765-785.

Kempf Jr, D. G. (2008). Corporate governance as religion. Journal of Regulatory Economics, $33(1), 117-131$.

Khan, S. R. (2012). The Sociology of elites. Annual Review of Sociology, 38(1), 361-377.

Khanna, T., \& Palepu, K. (2000). The future of business groups in emerging markets: Longrun evidence from Chile. Academy of Management Journal, 43(3), 268-285.

Kuran, T. (2009). Preface: The economic impact of culture, religion and the law. Journal of Economic Behavior \& Organization, 71(3), 589-592.

Kvale, S., \& Brinkmann, S. (2009). Interviews: Learning the Craft of Qualitative Research Interviewing. Los Angeles, CA: Sage.

Lau, C.-M., Fan, D. K., Young, M. N., \& Wu, S. (2007). Corporate governance effectiveness during institutional transition. International Business Review, 16(4), 425-448.

Lepoutre, J. M., \& Valente, M. (2012). Fools breaking out: the role of symbolic and material immunity in explaining institutional nonconformity. Academy of Management Journal, 55(2), 285-313.

Li, J., \& Qian, C. (2013). Principal-principal conflicts under weak institutions: a study of corporate takeovers in China. Strategic Management Journal, 34(4), 498-508.

Licht, A. N., Goldschmidt, C., \& Schwartz, S. H. (2005). Culture, law, and corporate governance. International Review of Law and Economics, 25(2), 229-255.

Lien, Y.-C., \& Li, S. (2013). Does diversification add firm value in emerging economies? Effect of corporate governance. Journal of Business Research, 66(12), 2425-2430.

Lipset, S. M. (1960). Political man: the social basis of modern politics. New York: Doubleday.

Lozano, M. B., Martínez, B., \& Pindado, J. (2016). Corporate governance, ownership and firm value: Drivers of ownership as a good corporate governance mechanism. International Business Review, 25(6), 1333-1343.

Lubatkin, M., Lane, P. J., Collin, S., \& Very, P. (2007). An embeddedness framing of governance and opportunism: towards a cross-nationally accommodating theory of agency. Journal of Organizational Behavior, 28(1), 43-58.

Luiz, J. M., \& Stewart, C. (2014). Corruption, South African Multinational Enterprises and Institutions in Africa. Journal of Business Ethics, 124(3), 383-398.

Maclean, M., Harvey, C., \& Chia, R. (2010). Dominant corporate agents and the power elite in France and Britain. Organization Studies, 31(3), 327-348.

Maguire, S., \& Hardy, C. (2009). Discourse and deinstitutionalization: The decline of DDT. Academy of Management Journal, 52(1), 148-178.

Mair, J., \& Marti, I. (2009). Entrepreneurship in and around institutional voids: A case study from Bangladesh. Journal of Business Venturing, 24(5), 419-435.

Markovska, A., \& Adams, N. (2015). Political corruption and money laundering: lessons from Nigeria. Journal of Money Laundering Control, 18(2), 169-181.

Marshall, B., Cardon, P., Poddar, A., \& Fontenot, R. (2013). Does sample size matter in qualitative research? a review of qualitative interviews in IS research. Journal of Computer Information Systems, 54(1), 11-22.

Marshall, M. N. (1996). Sampling for qualitative research. Family practice, 13(6), 522-526. 
Mason, M. (2010). Sample size and saturation in $\mathrm{PhD}$ studies using qualitative interviews. Forum: Qualitative Social Research, 11(3).

Mayring, P. (2000). Qualitative content analysis. Forum: Qualitative Social Research, 1(2). McCleary, R. (2008). Religion and economic development. Policy Review, 148.

Meyer, J. W., \& Rowan, B. (1977). Institutionalized organizations: formal structure as myth and ceremony. American Journal of Sociology, 83(2), 340-363.

Mills, C. W. (2000). The power elite. Oxford: Oxford University Press.

Nahavandi, A. (2006). The art and science of leadership. Upper Saddle River, NJ: Prentice Hall.

Nakpodia, F., Adegbite, E. Amaeshi, K. and Owolabi, A. (2016) Neither Principles nor Rules: Making Corporate Governance work in Sub-Saharan Africa. Journal of Business Ethics. Forthcoming. DOI: 10.1007/s10551-016-3208-5

Neu, D., Everett, J., Rahaman, A. S., \& Martinez, D. (2013). Accounting and networks of corruption. Accounting, Organizations and Society, 38(6), 505-524.

Neu, D., Rahaman, A. S., Everett, J., \& Akindayomi, A. (2010). The sign value of accounting: IMF structural adjustment programs and African banking reform. Critical Perspectives on Accounting, 21(5), 402-419.

Ngobo, P. V., \& Fouda, M. (2012). Is 'Good'governance good for business? A cross-national analysis of firms in African countries. Journal of World Business, 47(3), 435-449.

Norris, P., \& Inglehart, R. (2011). Sacred and secular: religion and politics worldwide (2nd ed.). Cambridge: Cambridge University Press.

North, D. C. (1990). Institutions, institutional change and economic performance. Cambridge: Cambridge University Press.

Ntim, C. G., \& Soobaroyen, T. (2013). Corporate governance and performance in socially responsible corporations: New empirical insights from a Neo-Institutional framework. Corporate Governance: An International Review, 21(5), 468-494.

O'Sullivan, N. (2000). The impact of board composition and ownership on audit quality: Evidence from large UK companies. The British Accounting Review, 32(4), 397-414.

Ogbeidi, M. M. (2012). Political leadership and corruption in Nigeria since 1960: A socioeconomic analysis. Journal of Nigeria Studies, 1(2), 1-25.

Oghojafor, B., George, O., \& Owoyemi, O. (2012). Corporate Governance and National Culture are Siamese Twins: The Case of Cadbury (Nigeria) Plc. International Journal of Business and Social Science, 3(15), 269-278.

Okafor, E. E. (2013). Corruption and implications for industrial development in Nigeria. African Journal of Business Management, 7(29), 2916-2924.

Okike, E. N. (2007). Corporate governance in Nigeria: the status quo. Corporate Governance: An International Review, 15(2), 173-193.

Oliver, C. (1992). The antecedents of deinstitutionalization. Organization Studies, 13(4), 563588.

Omololu, O. T. (2007). Corruption, governance and political instability in Nigeria. African Journal of Political Science and International Relations, 1(2), 28-37.

Osemeke, L., \& Adegbite, E. (2016). Regulatory multiplicity and conflict: towards a combined code on corporate governance in Nigeria. Journal of Business Ethics, 133(3), 431-451.

O'Shannassy, T., \& Leenders, M. A. (2016). Avoiding the "too comfortable in the saddle" syndrome: Obtaining high performance from the chairperson, CEO and inside directors. Journal of Business Research, 69(12), 5972-5982.

Osoba, S. (1996). Corruption in Nigeria: historical perspectives. Review of African Political Economy, 23(69), 371-386. 
Osuagwu, G. O., \& Obumneke, E. (2013). Multinational corporations and the Nigerian economy. International Journal of Academic Research in Business and Social Sciences, 3(4), 359-369.

Otusanya, O. J., Lauwo, S., Ige, O. J., \& Adelaja, O. S. (2015). Sweeping it under the carpet: the role of legislators in corrupt practice in Nigeria. Journal of Financial Crime, 22(3), 354-377.

Patton, M. Q. (2002). Qualitative evaluation and research methods (3rd ed.). Newbury Park, Calif.: Sage Publications.

Peng, M. W., Wang, D. Y., \& Jiang, Y. (2008). An institution-based view of international business strategy: A focus on emerging economies. Journal of International Business Studies, 39(5), 920-936.

Polit, D. F., \& Beck, C. T. (2012). Nursing research: principles and methods (8th ed.). Philadelphia, PA: Lippincott Williams \& Wilkins.

Rahaman, A. S., Everett, J., \& Neu, D. (2007). Accounting and the move to privatize water services in Africa. Accounting, Auditing \& Accountability Journal, 20(5), 637-670.

Rizvi, F. (2015). Circulation of elite in West and in Pakistan: historical perspectives. Journal of the Punjab University Historical Society, 28(1), 41-64.

Sampson, I. T. (2014). Religion and the Nigerian state: situating the de facto and de jure frontiers of state-religion relations and its implications for national security. Oxford Journal of Law and Religion, 3(2), 311-339.

Sariol, A. M., \& Abebe, M. A. (2017). The influence of CEO power on explorative and exploitative organizational innovation. Journal of Business Research, 73, 38-45.

Schreier, M. (2012). Qualitative content analysis in practice. London: Sage Publications.

Schuchter, A., \& Levi, M. (2015). Beyond the fraud triangle: Swiss and Austrian elite fraudsters. Accounting Forum, 39(3), 176-187.

Scott, W. R. (2004). Institutional theory. In G. Ritzer (Ed.), Encyclopedia of Social Theory (Vol. 11, pp. 408-414). Thousand Oaks, CA: Sage.

Scott, W. R. (2014). Institutions and organizations: ideas, interests and identities. Los Angeles: Sage.

Searle, J. R. (2005). What is an institution? Journal of Institutional Economics, 1(1), 1-22.

Shleifer, A., \& Vishny, R. (1993). Corruption. The Quarterly Journal of Economics, 108(3), 599-617.

Shleifer, A., \& Vishny, R. W. (1997). A survey of corporate governance. The journal of finance, 52(2), 737-783.

Sikka, P. (2017). Using freedom of information laws to frustrate accountability: Two case studies of UK banking frauds. Accounting Forum.

Solomon, J. (2013). Corporate governance and accountability (4th ed.). Chichester: John Wiley \& Sons.

Stastna, K. (2013). Do countries lose religion as they gain wealth? CBC News. Retrieved January 20, 2017, from http://www.cbc.ca/news/world/do-countries-lose-religion-asthey-gain-wealth-1.1310451

Stigliani, I., \& Ravasi, D. (2012). Organizing thoughts and connecting brains: Material practices and the transition from individual to group-level prospective sensemaking. Academy of Management Journal, 55(5), 1232-1259.

Suddaby, R. (2010). Challenges for institutional theory. Journal of Management Inquiry, 19(1), 14-20.

Tignor, R. L. (1993). Political corruption in Nigeria before independence. The Journal of Modern African Studies, 31(2), 175-202.

Trompenaars, F., \& Hampden-Turner, C. (2004). Managing people across cultures. New York: Wiley. 
Tsamenyi, M., \& Uddin, S. (2009). Introduction to corporate governance in less developed and emerging economies. Research in Accounting in Emerging Economies, 8, 1-11.

Uche, C. O., Adegbite, E., \& Jones, M. (2016). Institutional shareholder activism in Nigeria: An accountability perspective. Accounting Forum, 40(2), 78-88.

Udama, R. A. (2013). Understanding corruption in Nigeria and its implications to national security and sustainable development. IOSR Journal of Humanities and Social Science, 10(1), 60-73.

Vergara, L. G. (2013). Elites, political elites and social change in modern societies. Revista de Sociología, 28(31-49).

Warren, M. E. (1996). Deliberative democracy and authority. American Political Science Review, 90(1), 46-60.

Warren, R. C. (2003). The evolution of business legitimacy. European Business Review, 15(3), 153-163.

Weber, R. P. (1990). Basic content analysis (2nd ed.). London: Sage.

Woodward, D., Edwards, P., \& Birkin, F. (2001). Some evidence on executives' views of corporate social responsibility. The British Accounting Review, 33(3), 357-397.

$\mathrm{Wu}, \mathrm{X}$. (2005). Political institutions and corporate governance reforms in Southeast Asia. In H. K. Leong (Ed.), Reforming corporate governance in Southeast Asia: Economics, Politics and Regulations. Singapore: Institute of Southeast Asian Studies (ISEAS) Publications.

Yakasai, A. G. (2001). Corporate governance in a third world country with particular reference to Nigeria. Corporate Governance: An International Review, 9(3), 238-253.

Zald, M. N., \& Lounsbury, M. (2010). The wizards of Oz: towards an institutional approach to elites, expertise and command posts. Organization Studies, 31(7), 963-996.

Zattoni, A., \& Cuomo, F. (2008). Why adopt codes of good governance? A comparison of institutional and efficiency perspectives. Corporate Governance: An International Review, 16(1), 1-15.

Zucker, L. G. (1987). Institutional theories of organization. Annual Review of Sociology, 13, 443-464.

\section{Appendix - Interview Guide}

\section{Interview Background}

a. As a stakeholder in corporate governance in Nigeria, how would you assess the present state of corporate governance in Nigeria?

b. What are the main problems confronting corporate governance in the country? 


\section{Institutional Influences}

a. To what extent do you think that the following elements have impacted the practice of corporate governance in Nigeria;

○ Political system

○ Corruption

○ Culture and Ethnicity

$\circ$ Extent of Law and Order in the society

$\circ$ Religion

b. How can the impact of the above issues on corporate governance be minimised?

\section{SEC Code of Corporate Governance (2003 and 2011)}

a. How would you access the contributions of the SEC codes (both 2003 and 2011) to the practice of corporate governance in the country?

b. What is your view on codes reflecting the preferences of key drivers of the institutional environment?

\section{Necessary Reforms}

a. In your opinion, what governance reforms are necessary to improve corporate governance in the Nigerian business environment especially regarding the influences of key stakeholders?

Thank you. 